\title{
MARXIST ANTHROPOLOGY: PRINCIPLES AND CONTRADICTIONS
}

\author{
NEW PERSPECTIVES IN THE SCIENCE OF MAN
}

\author{
PART II: RELATIONS TO NATURE; \\ ABSTRACT AND CONCRETE LABOR*
}

\section{VII \\ LABOR, WORK AND HUMAN CULTURE}

Any anthropology that calls itself Marxist must have as its starting point the intermediation of labor between human society and nature. The labor is abstract labor; as concrete labor it is work. The society in question is not society in general or the human community in abstracto, but a particular, historical society, whether primitive or civilized. The question that is posed thereby is twofold: first, it is the problem of the place in nature of the human kind, or the problem of location; second, it is the historical problem of the transition of humanity from the natural to the cultural order. Nature has its history, as does the human society, but the unit that we take for the observation of natural history is far wider than the unit of observation of human history. In the former case it is the biological species whose history is taken up; in the case of human history it is the communal life of the village, and the social life of the tribe, city or nation. The time period of natural history is geological time, which is one or more orders of magnitude greater than the time periods of ethnography and historiography. ${ }^{1}$

* Continued from the previous issue, pp. 236-72.

1 The category of culture as the differentia specifica of the human kind is a notable contribution of empirical anthropology in the past hundred years. It is proposed as the species-wide phenomenon of the human kind that is shared by no other species. The defect in the proposal lies in its abstraction, for the human capacity for production of speech or the products of labor in the form of a specific form of speech or product is only partly accounted for in this way. The category of abstract culture, or the abstraction of the human capacity, designates a field of scientific investigation; it does not express the results of that investigation in the form of laws. The interaction between the abstraction and the concretion as the means to these laws has not been developed by the cultural anthropologists. 
The thesis of the natural science of society is that of the positive science of the nature of human society; if it is left without further development, it is a form of positivism, which is on the one side a falsification of the place of the human species in nature and a simplification of the problem of anthropology; it is the elimination of the difference between the human and natural orders, and the elimination of the difference between the sciences of humanity and nature. The natural science of human society is a potentiality of the sciences which is to be developed, but not in its present form; it is on the contrary the thesis of the science of human nature as the science of nature and its negation. The continuity between the human kind and nature is coupled with the discontinuity; the positive science of nature is inseparably linked with its negation, the science of human nature; and the latter in its abstract form is coupled with its concretion, the particular ethnographic and historical accounts. ${ }^{1}$ T. H. Huxley, the ally of Darwin, propounded the doctrine of the continuity between man and nature and the discontinuity; the discontinuity was conceived by him abstractly, as the absence of morality in nature. ${ }^{2}$ Max Scheler propounded the negative of this thesis, the discontinuity alone. ${ }^{3}$ Sartre has attempted to resolve the contradiction by introducing the distinction between the objective existence of nature and the subjective category of existence for $u$ s in the case of humanity, but far from having "saved" the phenomenon, his proposal has only mystified the relation between humanity and nature; Sartre has invented a new name for an old disease, he has not cured it. ${ }^{4}$

1 The attempt at a positive science of human society has its history. Auguste Comte and Emile Durkheim made their contributions to it; more recently it was propounded by A. R. Radcliffe-Brown, Natural Science of Society (Chicago, 1957).

2 T. H. Huxley, Man's Place in Nature (1863); id., "The Struggle for Existence in Human Society", in: The Nineteenth Century, February 1888.

${ }^{3}$ Max Scheler, Die Stellung des Menschen im Kosmos (1928). This line of subjective negativity extends from $A$. Schopenhauer to the twentieth-century phenomenologists, among whom Scheler was a leading figure. This movement had wrought its effect on existentialism in Sartre, see the following note.

- Sartre, Critique de la raison dialectique, p. 104: "En se réservant d'étudier, dans le secteur ontologique, cet existant privilégié (privilégié pour nous) qu'est l'homme, il va de soi que l'existentialisme pose lui-même la question de ses relations fondamentales avec l'ensemble des disciplines, qu'on réunit sous le nom d'anthropologie." The subjective index in human history is, according to Sartre, the privileged position in nature for us. We have by an imperious grasp accorded the privilege of position in nature to ourselves. The question is not: quo warranto, by what right, do we grasp; the question is, how is this imperious grasp arrived at, not its moral justification or denunciation. Further, the imperious grasp by the human kind that is here implied is the subjective evaluation of the ecological dominant, the human species in nature. That is a 
The question of the place of the human species in nature was set by Marx in reference to the intermediation by labor between the human society and nature; it was then linked by him to the Darwinian conception of the continuity-discontinuity between the human and the natural order. The intermediation by labor is the characteristic relation of the human species to nature. Considered abstractly it is the initial separation, distancing and alienation from nature of the human kind; concretely it is the production and reproduction of the means of life in a given society and a given mode of production. ${ }^{1}$ The intermediation by social labor is the cultural relation considered as an abstraction. Let us consider the three-figured field of humanity, labor and nature in their interrelations. In both anthropologies, of Marx and of the academic world, the intervention between the human kind and nature is conceived, in the one case by labor, in the other by culture. Labor and culture are in both cases conceived as social products; and in both cases the conception in the mind is related to the intervention in the life of the human species by culture on the one side, labor on the other. In this sense both anthropologies share a common principle. But this

mere projection back onto the past of the imperial grasp of political society (witness Rome) and the imperialist grasp of modern capitalist societies. If it is a privileged position for $u s$, then it can only be the product of political society; primitive society knows no privilege. The doctrine of Sartre is as bad ethnology as it is bad ecology. In the latter sense it is a pseudo-natural science of humanity, the projection of the viewpoint of the naturalist onto the human being, not his proper object; distancing of the observer from the observed, as though the two were not of the same order of nature and culture. This is positivism, it is a defective dialectic because it is onesided, it does not link the positivity with its negation, and it does not repair the omission of the objective side of its thesis.

1 Ókonomisch-Philosophische Manuskripte, op. cit., p. 83: "Das Produkt der Arbeit ist die Arbeit, die sich in einem Gegenstand fixiert, sachlich gemacht hat, es ist die Vergegenständlichung der Arbeit. Die Verwirklichung der Arbeit ist Vergegenständlichung." This thesis was conceived by Marx concretely in reference to capitalist society and production therein. It had been the thesis of Ludwig Feuerbach that man objectifies himself in creating a world of objects; it is held by many that Marx took over this thesis from Feuerbach in the Economic-Philosophic Manuscripts. (We will return to the problem of objectification at the end of this article.) The attribution of a Feuerbachian position to Marx as of 1844 is faulty because Marx had already gone beyond Feuerbach in the chapter "Die Entfremdete Arbeit", ibid., pp. 81-94. There the concept of mankind as an abstraction is overcome, and the Gattungswesen of humanity is taken up concretely. The alienation of labor from its product takes place in the concrete, historical society of Marx's observation, capitalist society. (The Gattungswesen is the generic being of humanity: see Kapital, Vol. 1, op. cit., p. 67, note). Marx had even gone beyond Feuerbach in 1843 when he composed his critique of the Hegelian Philosophy of Right, for in 1859 Marx referred to his own preoccupation with the material relations of life in this connection (MEW, Vol. 13, p. 8). 
is in turn contradicted, for the concept of culture in academic anthropology remains an abstraction, whereas labor was taken up abstractly and concretely by Marx.

The theory of social labor as it was developed by Marx was posited in terms of the relation of abstract to concrete labor, and is developed as a dialectic. It is in point, therefore, to take up this dialectic, for the positions both of academic anthropology and of existential anthropology can be submitted to a joint critique thereby. ${ }^{1}$

Human labor is a unitary process, the purposeful expenditure of labor power. In all forms of society save the most primitive it is a social relation, ${ }^{2}$ and in all forms of society, whether primitive or not, it is a relation to nature whereby natural materials are transformed. That unitary process in its concrete form is useful labor, and as such it is labor in society whose purpose is the production of objects for consumption. Labor in its concrete form is, in relation to nature, direct labor, which transforms the natural materials into objects useful to the particular society. That same unitary process of labor has, in all but the most primitive forms of society, an abstract form. These are the societies in which commodities, hence commodity value, are produced. This form of social labor is the expenditure of human labor power in the physiological sense; it is labor considered not in relation to the usefulness of the object but in relation to the equivalence of one amount of labor and another. The purpose of the equivalence is the determination of the commodity exchange value.

Again, in its abstract form labor in society is taken up in relation to the process of circulation rather than to that of production and of consumption. We have posited therefore two types of production in society, the first or most primitive being that in which production takes place in direct relation to consumption, the unit of production and of consumption being the same. In this mode of production there is no significant amount of exchange of products between the social unities that are the units of production, whether family or kinship band, kin village, etc.; in its predominant form, labor here takes the concrete form of production for direct consumption. The second type

${ }^{1}$ A. L. Kroeber and Clyde Kluckhohn, Culture, A Critical Appraisal (1952); Claude Lévi-Strauss, La Pensée Sauvage (Paris, 1962); id., Mythologiques. Le Cru et le Cuit (Ouverture) (Paris, 1964); Sartre, op. cit. See also Alfred Schmidt, Der Begriff der Natur in der Lehre von Karl Marx (Frankfurt, 1971); Hannah Arendt, The Human Condition (New York, 1959).

${ }^{2}$ In the most primitive forms of society there is no separation of the relations of labor in the family, in the small band of kinsmen, and in society. We will leave open the question whether social labor on the one side and the division of social labor on the other can be ascertained in those circumstances. Engels thought that they could be so ascertained (MEW, Vol. 23, p. 372). 
of labor is that in which the unit of production is clearly separated from the unit of consumption, and exchange of products on a considerable scale takes place between the producing units. At this point social labor properly so called is posited, and we may now take up the distinction between social labor as abstract and concrete relations to nature and in society for the first time in history. At the same time the distinction between direct and indirect labor processes is posited, or the dual forms of labor in relation to nature and in society. The increasingly indirect relation to nature is measured by the increasing number of steps in the concrete labor process or in the number of instruments to make instruments; and this constitutes a simple index of the alienation from nature, for it is the primary measurement of that form. It is production for further production. The increasingly indirect relation of labor in society is at the same time production in society for further circulation through exchange; it is production for indirect consumption. With the introduction of the relation of concrete and abstract social labor the direct and indirect relations of production and circulation in society are promulgated. These are dialectical moments of transformation of society. They are ranged on a chronological scale: the simpler or more direct takes place earlier in time, nearer to the beginnings of culture; the more complex, with more numerous stages of mediation in production, takes place later. ${ }^{1}$ The dialectical moments of labor in society are real, being at once actual, typical and temporal. They take place in the brain and in society, for the relations of labor to nature and in society are not merely correlative to one another but are mutually determinant in their evolution from simple to complex forms.

Engels directed attention to the distinction between labor and work, which is parallel to Marx's distinction between abstract and concrete labor; as concrete labor it is work, the production of use-values; as abstract labor it is labor in short, the production of commodity value. ${ }^{2}$ Labor as the creator of use-values is independent of any particular social end, purpose, relation, condition of human existence; as abstract labor it is abstracted from any given society, being the general material

1 Marx, Kapital, Vol. 1, p. 61. On cultural beginnings ibid., pp. 194, 353, 535.

2 Marx, Capital, Friedrich Engels ed., English tr. S. Moore, E. Aveling, E. Untermann (New York, 1936), pp. 54, 207. Hannah Arendt, op. cit, writes in this connection, p. 322: "The German Arbeit applied originally only to farm labor executed by serfs and not to the work of the craftsman, which was called Werk." This is a rural-urban opposition, or of labor in the field and work in the town or indoors; it is implicit in the distinction between the labor of the body and the work of the hands. Both conditions were bound in the European Middle Ages, when all were pro forma unfree, even kings. 
interchange between the human kind and the natural environment. ${ }^{1}$ Agriculture is an application of the science of the material interchange with nature. ${ }^{2}$ Work is the expenditure of labor power to a concrete end, on the one side the production of a given product of consumption, and of commodities on the other.

John Locke had distinguished between the labor of one's body and the work of one's hands, implying the completion of a task for a specific purpose by work, and a general relation to nature by labor. ${ }^{3}$ The dual process in Locke's system has a twofold consequence: labor and work jointly exclude from nature the natural stuff, and appropriate it to human use, a primary alienation. But thereby the common enjoyment is excluded, and private ownership as a right is established; and therein lies Locke's naiveté. The initial distinction between labor and work in Locke was explicitly stated in another way by Adam Smith, who wrote of labor in the sense of abstract labor, and of work in the sense of completed end products; Smith cited the French Encyclopédie, in which the distinction between travail (labor in general) and ouvrage (a completed piece of work) was made. ${ }^{4}$ Hegel wrote of Arbeit (labor) as distinct from Werk (work); by the former he meant undertakings relative to meeting of wants, writing in the same sense as political economists of the time. ${ }^{5}$ Hegel opposed labor as process directly related to nature by wants and desires to work as mediated human effort: man goes mediately to work (vermittelnd zu Werke); the mediation of the instruments of labor is twofold, in relation to wants and in relation to the end product. ${ }^{6}$ In Hegel as in the earlier writers there is the fundamental error of abstraction. Wants and desires are not natural, nor are they invariable. They vary from one society to the next, they are culturally variable, and already from the outset in seeking for a starting point of human nature we find that it cannot be found: human nature is absorbed into culture; the process disappears

1 Marx, Kapital, Vol. 1, pp. 57, 198f. See Vol. 3, op. cit., p. 828.

2 Marx, Grundrisse der Kritik der politischen Okonomie, op. cit., p. 592.

3 John Locke, An Essay Concerning the True Original, Extent and End of Civil Government (1690), ch. V, § 27.

- Adam Smith, The Wealth of Nations, E. Cannan ed. (New York, 1937), pp. 7,86 .

5 Hegel, System der Sittlichkeit, in Sämtliche Werke, VII (1913), pp. 422ff. (here mechanical labor as negative, practical is distinguished from living labor); id., Enzyklopädie der philosophischen Wissenschaften, in Werke (Frankfurt), X, § 524. Further to this theme see: W. R. Beyer, "Der Begriff der Praxis", in: Deutsche Zeitschrift für Philosophie, VI (1958); I. Dubský, 'Hegels Arbeitsbegriff und die idealistische Dialektik [Rozpravy Ceskoslovenské Akademie Věd, LXXI, 14] (Prague, 1961).

- Hegel, Philosophie der Geschichte, in Werke, XII, p. 295. 
in the product. The generality of the human nature is absorbed in the human being; but that human being is the product of two dialectical moments, one abstract, or culture in general, and the other concrete, or the particular culture, giving particular form and intent to desires. The abstraction and concretion are to be grasped in their interrelation, as a general potentiality and its actualization in concreto. Marx's category of labor was expressed in parallel with his category of culture, but only the former was fully worked out. Both are necessary in reference to the abstract problem of the place in nature of the human kind.

The material interchange with nature is the abstract form of labor, whereby the natural stuff is transformed in accordance with human design. The interchange in the form of constant return allows no surplus; death leaves no excedent over, just as the second law of thermodynamics operates upon human-organic and inorganic matter. At the same time, a formal interchange takes place along with the material interchange, but that formal interchange lies wholly within the cultural sphere. Once the materials have been extracted from nature they move about for a time in society before their eventual return. The movement of the products of concrete labor in society is the metamorphosis of form of goods into commodities, commodities into money, and back into commodities. ${ }^{1}$ The formal and material metamorphoses are both found in political society in the circulation process. The formal interchange in circulation was systematically elaborated by Marx, whereas the material interchange with nature was set forth in aphoristic insights; it is nevertheless the material basis of Marx's value theory. The metamorphosis, as material interchange, is the transformation of matter from the domain of nature to that of culture, of natural matter, that is, into value in use in human society in general, and into value in use and exchange in political society, in particular. As formal change it is the expression of value in the abstract form in which it circulates in the economy of the political society, or the political economy.

The labor of the body is the means of comportment by the human kind as a whole with regard to the resources of nature. In political society this comportment is the exploitation of the natural resources, carried through with ever increasing intensity; this relation is always temporary, even if the time period which it embraces be measured in centuries, or hundreds of thousands of years. The labor of the body is the material condition of human existence in particular and the material condition of organic existence in general. This is the ecological

${ }^{1}$ Marx, Grundrisse, p. 559; Kapital, Vol. 1, pp. 128, 134. 
judgment, however, which we must make more precise, as opposed to the economic. The science of ecology studies the relations of living organisms and species to the natural environment. The science of human ecology has taken over the models of botanical and zoological ecology, as though the human relations to nature were no different from those of trees and bees. But the science of human ecology is to this extent a pseudo-science, and the models pseudo-models, for the relations of the particular human societies to nature are both mediate and direct, whereas those studied by botany and zoology are solely direct. The economic relations, on the contrary, including the relations to nature, whereby the natural goods and bounties are exploited, are mediate. Taking the history of the human kind as a whole, in all its variations, over the hundreds of thousands of years of its existence, all the mediate relations are cancelled out; there is only the natural order, of which the genus homo is a part, including all the doings, works and effects of the human kind. The economic relation is negated, and the science of political economy is cancelled out therefore; there remains only the ecological relations of the world of nature. This is the converse of the teleological explanations. There the universal teleology, or the guiding line that regulates and controls human evolution as a whole, is a purely speculative conception, whereas the particular teleologies, as particular relations of means and ends, are the specific modes of comportment and relations of the human kind among themselves and to the natural surroundings. In the same way, the economic relation in reference to the human kind, when taken as a whole, is a false judgment, for it attributes a universal telos to the human relation to nature. There remains only the macro-ecological relation, of which the genus homo is a part, without an end or entelechy.

The labor of the body, as the material interchange with nature, is at once an ecological and an economic relation, an unceasing process. The ceaseless interchange between the living human body and the natural world is effected in the production of useful things; concrete wants are thereby met in concrete ways. The labor of the body is concrete labor, the original and ultimate form of labor, shared with all living organisms. The process is circular, returning in the form of wastes of the organism, and returning in death, to the soil, air and water what it has taken in life. The work of the hands, on the contrary, is human alone, being both abstract and concrete. But whereas the labor of the body as ceaseless, continual process is concrete, the work of the hands, in the form of abstract labor, is continual, unbroken process. As concrete labor the work of the hands is the production of useful things, it is production with an end in view. Abstract labor, in the condition of political society, is the creation of exchange value in 
the process of social production. The abstract labor is converted into its concretions thereupon, which are the commodities. The concrete labor is the original concretion, and remains nothing but concrete; it is the labor of the body. The natural material is given a new form by the combination of the entire relations of labor, abstract and concrete; but that labor is transformed into the interchange of forms, that is, by the exchange of equivalent values, in society. It becomes social labor. The amount of the transformation is measured by the quantity of abstract labor applied and consumed in the process of production.

The opposition drawn by Locke between labor and work is the process viewed from the standpoint of living labor, that is, from within the labor process, within the human being, from which standpoint the distinction between the whole and the part, as between the entire human organism and the belly, heart or fingers, is a vital one. The opposition between labor and work drawn by the Encyclopedists, Smith, Hegel and Engels is the same viewed from without, according to whether it is the process or the product that is considered. Marx drew the different lines together in the system of oppositions, abstract and concrete labor, living labor and dead, congealed labor time. In its content, living labor is analyzed into abstract process; in its form it is exchangeable value that is produced. In its content, again, it is usevalue. The living labor power is sublated as congealed labor time, the commodity whose expression is its exchangeable value. The potentiality is thereby converted into its actuality, the finished piece of work is the actualization of the potentiality, the Hercules in the marble laid bare by the sculptor's chisel and mallet. The completed product or finished work is converted into its opposed form, the material process of interchange with nature by its consumption, whereby the product is sublated in the process. The oppositions of abstract and concrete labor, potential and actual, or labor and work, are set up hypothetically, in reality the two sides of the opposed pairs are one. The opposition of hand labor and head labor is likewise an artificial one, constructed by the division of labor in political society. The artificial opposition is now being promulgated at an ever accelerating rate, having extruded at the same time its ideological expression. The opposition of hand and head labor is, however, but a further step in social alienation. Intellectuals who have propounded this opposition in the twentieth century attribute the term "head labor" to their alienated and at once privileged state; it is in their interest to do so. But they do not ennoble themselves by this self-serving device. 


\section{VIII}

\section{ACCUMULATION AND REPRODUCTION}

The relation of the empirical and positive science of anthropology to its subject matter rests in no small measure on the contributions of Darwin, who, perhaps more than anyone else in his time, established the doctrine of continuity between the human species and the natural order generally. He argued against finality in nature, whether as final cause, form or thing; further, he argued against fixed categories, and in favor of change, the movement of a species into what it is not, or its opposite. But he came upon the notions of impermanency and struggle not by reflecting on the processes of nature; they came from his reading of Thomas Malthus, the doctrine of scarcity of food and of need to restrict the numbers of the poor; his understanding of nature came through application of an ideology convenient and comfortable to nineteenth-century capitalism. ${ }^{1}$

The relation of Marx to Darwin was ambivalent, the relation of the systems of the two men no less so. ${ }^{2}$ On the one side Marx opposed the Malthusian aspects of Darwin's theory, in reference to the struggle for life and the law of population. ${ }^{3}$ On the other Marx accepted the Darwinian system of natural history as a blow against teleology in the natural sciences. The positive content of Darwin's doctrine provides the basis not for Malthusianism, but for the class struggle in history. Darwin, says Marx, transfers the concepts of division of labor, competition, opening up of markets, technological inventions from English society and recognizes it among beasts and plants, summing this up in the Malthusian struggle for existence. ${ }^{5}$ But this notion applies to

1 The alarm over depletion of oil resources is but one phase of a worldwide depletion of the stocks of nature. See Harrison Brown, The Challenge of Man's Future (New York, 1954). Written from a Malthusian point of view, this book raises the problem of the extraction of the natural resources for profit. As useful product the trees of the forest are hewn, as surplus product the forest is depleted. 2 Marx offered to dedicate the second volume of Capital to Darwin, who declined the offer because of the feelings of his family. International Review of Social History, IX (1964), p. 465.

${ }^{3}$ It appears to be a widespread notion that Darwin owed the idea of the struggle for life to Herbert Spencer; this has been most recently published by Jacques Monod, Le hasard et la nécessité (Paris, 1970), pp. 135f. But Darwin himself attributed the idea of survival of the fittest, together with its expression, to Herbert Spencer, and brought out the idea of struggle for life in connection with Thomas Malthus's notion of the geometric increase of population. On Marx's opposition to Darwin, see letter to L. Kugelmann, 27 June 1870, in Marx and Engels, Selected Correspondence, 2nd ed. (Moscow, 1965), p. 239.

4 Marx, letter to F. Lassalle, 16 January 1861, ibid., p. 123.

- Marx, letter to Engels, 18 June 1862, ibid., p. 128. 
human beings alone. It is the ideology of Malthusianism transformed into a pseudo-scientific doctrine, and then applied to the natural biota. Hegel describes civil society as the spiritual animal kingdom; Darwin turns this upside down: the animal kingdom figures as civil society.

Darwin applied the ideology, hence the categories, of English society to the study of nature; Marx applied the method of natural history to the critique of political economy. But Darwin, we have seen, made the philosophy of nature into the history of nature, for in destroying the notion of fixity of species he proposed laws of change by accumulation of differences through natural selection. Darwin argued in favor of determination of form through function, and against the personification of nature and natural forces, and he looked on "the struggle for existence" as a metaphor. ${ }^{1}$ The fundamental problem for Marx was, as it is for us, how the laws of human and natural history are related. Although we may acknowledge that potentially the human species and the kingdom of nature are one, in actuality they are alienated from each other, and the means for the reunification are not within reach. Nature and mankind will both be changed in order to realize this potentiality; the way to effect the required changes is subject in part to our control. We are faced, then, with the problems of changes in the dialectical moments of form in relation to function, accumulation of differences, and production in relation to reproduction.

1. Marx quoted Darwin as having written: "So long as one and the same organ has different kinds of work to perform, a ground for its changeability may possibly be found in this, that natural selection preserves or suppresses each small variation of form less carefully than if that organ were destined for one purpose alone. Thus, knives that are adapted to cut all sorts of things may, on the whole, be of any shape; but an implement destined to be used exclusively in one way must have a different shape for every different use." ${ }^{2}$ Darwin wrote that naturalists had devised a scale of nature in which beings that stand low are more variable than those which are higher. He continued: "I presume that lowness here means that the several parts of the organization have been but little specialized for particular functions; and as long as the same part has to perform diversified work, we can perhaps see why it should remain variable, that is, why natural selection should not have preserved or rejected each little deviation of form as carefully as when the part has to serve for some special purpose. In the same way that

1 Darwin, The Origin of Species, op. cit. Against fixed species, passim; on accumulation, pp. $66,33,36,52$; on natural selection, pp. 14, 29, 367; against personification of nature, p. 64; on struggle for existence as metaphor, pp. 52,66 .

Marx, Capital, English tr., op. cit., p. 375, note. 
a knife which has to cut all sorts of things may be of almost any shape; whilst a tool for some particular purpose must be of some particular shape."1

Nature includes both lower and higher beings. It remains to be shown that the movement is progressive, from lower to higher, or from less specialized, variable, to more specialized, and particular in shape. Darwin developed this in the following way: although he denied consciousness and volition to the workings of the laws of nature, yet he asserted the existence of these laws, without the active power of Deity, by natural selection, which "can act solely through and for the advantage of each being". ${ }^{2}$ Man stands high in the organic scale, arising out of lower forms, whose traces are still to be found in the human frame; the movement from lower to higher is effected by our intellectual powers and by the social qualities of mutual aid; these powers and qualities have arisen in turn by natural selection through competition, together with the inherited effects of habit. ${ }^{3}$

2. The question of form and content must be separately raised before we can further consider the relations of natural to social laws in the works of Marx and Darwin. The natural laws serve either as models for the formulation of social laws or they are different versions of the same laws. In the former case they differ in their respective content; in the latter case they differ in form. The natural-science paradigm for social science assumes a like content up to a certain degree, whereas the method of the natural sciences is more highly developed and can be copied by social scientists where the likeness of content has been suggested. This may be examined relative to the concept of accumulation.

Marx distinguished between accumulation in general and capitalist accumulation in particular, showing the error of Malthus and Jones, who failed to make this distinction. ${ }^{4}$ Capitalist accumulation is characterized by capital-begetting capital (Selbstverwertung des $\mathrm{Ka}$ pitals). ${ }^{5}$ The process of capital formation comes from the labor process, which is the means to expand the value of capital; capitalist production is nothing other than this process of valorisation, capitalist

${ }^{1}$ Darwin, cp. cit., p. 112.

2 Ibid., pp. 64, 112. On advantage and utility of variations, p. 98; on. Darwin's own utilitarianism, p. 146.

${ }^{3}$ Ibid., pp. 444f. There is at present a controversy over "non-Darwinian" evolution, i.e., evolution by random processes rather than selection and fitness. But Darwin had already drawn attention to maintenance as opposed to change by natural selection. It would therefore be in point to speak of randomness in maintenance as well as in evolution and change.

4 Marx, Kapital, Vol. 1, p. 614.

Ibid., p. 386. 
reproduction is a means of reproducing value as capital, as selfexpanding value. ${ }^{1}$ Reproduction is an economic process both in primitive and in civilized societies, and in any mode of production, whether Asiatic or capitalist. In its simpler forms, e.g., in primitive society, or in the Asiatic mode of production, it is simple accumulation, Häufung. ${ }^{2}$ The simpler forms have likewise gone through their internal development. In primitive societies, the process of development is slow, the process of handicraft manufacture is conducted unmindful of time. Implements have evolved, says Tylor, by small successive changes; he also remarks that a primitive tool maker can take a whole month for the preparation of an arrow. ${ }^{3} \mathrm{~A}$ change in relation to time applied to laboring, e.g., in the agricultural fields, is to be seen in the Asiatic mode of production; time is now subjected to a human scale. On the contrary the hunt or gathering of wild plants in primitive societies is conducted according to the cycles imposed by natural events. Considered as an economic category, reproduction has under all human conditions a time factor to which it is associated, but under civilized conditions this time factor comes under social control to an increasing degree. The time factor in reproduction is fixed at first by natural, then by social inventions. ${ }^{4}$

The key to reproduction is accumulation, but in order to accumulate, one must first store up; immediate consumption is to be avoided. The physical storage of primitive economies is replaced in the capitalist

1 Ibid., p. 591. "The economic character mask of the capitalist is attached to the person such that his money functions as capital." Professor Robinson appears to have sought in vain for the inner determinant of capitalist accumulation, while criticizing Rosa Luxemburg for maintaining the thesis of an external accumulation process ("economic imperialism"). See Joan Robinson, Introduction to Rosa Luxemburg, The Accumulation of Capital (New York, 1951). On valorization see Le Capital, op. cit., pp. 257, 279.

${ }^{2}$ Marx, Kapital, Vol. 1, pp. 363f. Contrary to a widely held notion in certain socialist circles and elsewhere, primitive reproduction is an economic process and has nothing to do with biological-sexual reproduction.

${ }^{3}$ E. B. Tylor, Anthropology (1881), I, ch. VIII; id., Researches into the Early History of Mankind and the Development of Civilisation (1865). Cf. Marx, Kapital, Vol. 2, in MEW, Vol. 24, p. 437.

- Lewis Mumford, Technics and Civilization (New York, 1963), has imagined that orderly time-keeping was invented in medieval European monasteries, and that Eastern civilizations "flourished on a loose basis of time". The appreciation of time-keeping in Asia is other in Joseph Needham, Science and Civilisation in China (Cambridge, 1954 and on), and in his Clerks and Craftsmen in China and the West (Cambridge, 1970). In civil or political society, of both Europe and Asia, concrete labor time and abstract time-keeping come increasingly under human control; both are contrasted with loose or non-existent time-keeping, or its control by natural processes, as noted in Tylor and Marx (see preceding note). 
mode of production by accumulation in constant capital, in means of production, in machines to make machines; in both primitive and capitalist modes of production, however, the skill of the laborers is stored up and accumulated. The storage of the computer is in this sense an accumulation; it is not a change in direction of the process from the primitive labor to capitalist labor in factories; it is, however, an increasing distantiation and alienation of the workers. Hodgskin wished to defend labor against capital as productive of value, contra Ricardo; value is stored-up labor, according to the former. ${ }^{1}$ He failed, said Marx, to distinguish between living and dead labor; and he did not understand the real causes of the fetishization of capital. ${ }^{2}$ Money, according to Hodgskin, will give anyone command over the labor of some men, over the labor realized in commodities, as well as over the reproduction of this labor, and to that extent over labor itself. Hodgskin's argument to prove the dependence of the laborer on the coexisting labor of other laborers as opposed to the dependence on previous labor was intended to set aside the "storage phrase". But, wrote Marx,

"What is really stored up, although not as a dead mass, rather as living, is the skill of the laborer, the degree of development of labor. To be sure (what Hodgskin does not bring out, for it serves on the contrary the crude conception of the economists, is to place the accent on the Subject, on the subjective in the subject so to speak, in opposition to the matter), the separate stage of development of the productive power of labor, which is the point of departure, is present not only as capacity, ability of the worker, but at the same time in the objective organs which this labor has created for itself and daily renews. This is the true prius which makes the starting point, and this prius is the result of a developmental course. Storing up is here assimilation, continuous maintenance and at once reshaping of the already transmitted, made actual [verwirklicht]."3

1 Thomas Hodgskin, Labor defended against the claims of capital; or the unproductiveness of capital proved (London, 1825).

Marx, Theorien über den Mehrwert, III, op. cit., pp. 259ff., 285ff. The storage is unrelated to abstinence, which is falsely associated with early capitalism, Puritanism, etc. Cf. Kapital, Vol. 1, pp. 620ff.; Marx has many sarcastic comments on asceticism, etc. On cumulation of stock (contra Adam Smith) see Marx, Kapital, Vol. 2, op. cit., p. 142 and note. On storing up (ante-Darwin) see Marx, Grundrisse, p. 7: No production without stored-up past labor, even if this labor is but the dexterity accumulated and concentrated in the hand of the savage with repeated practice. (This is the caricatured presentation by the "modern" economists.)

s Theorien über den Mehrwert, III, p. 289. 
Up to this point we have been concerned with the relations in society and those within the socialized individual, the human being. The skill of the worker is developed in society, stored up and transmitted; the skills are maintained and renewed in the hand, eye, judgmental capacity; they have an objective and a subjective relation in the individual. The realization of labor as work is the dead labor, the fulfillment of the capacity, that is, of the potentiality; the already transmitted is that which is finished, and is then stored up, accumulated as capital. The stored-up capacity of the worker is transmitted by another process and has a different relation to nature. The subjective element in the storage and transmission of skills is paired with the objective element in production; the latter is the development of the productive power of labor, which is found in the hand and eye of the worker and in the instruments that he uses in his labor. The productive capacity of the worker has, again, both a subjective and an objective element, comprising the ability of all mature human beings to learn and transmit the skills of labor, which is in turn both subjective and objective, and the objective element of application in the labor process of the acquired skill. These relations of subjectivity and objectivity have their parallel in nature; the accumulation of capital is set on one side, the accumulation of the working skills on the other. This is important enough to bring out even though it might serve the purpose of the enemies of labor, the economists who sought to stress the subjective element in the process of production, in opposition to the material. It is in the accumulation of the working skills that the parallel between the human and the natural processes was developed by Marx, who continued:

"It is in this latter way that Darwin makes storing up through inheritance in everything organic, plants and animals, into the driving principle of its formation so that the different organisms themselves form themselves through 'storage', and are but 'inventions', gradually cumulated inventions of the living subjects. But this is not the sole prius for production. For plants and animals it is external nature, including therefore the inorganic, as well as their relations to other plants and animals. Human beings, who produce in society, in this way come upon an already modified nature (in particular the natural is also transformed into an organ of mankind's own activity) and particular relations of producers to each other. This accumulation is in part the result of the historical process, in part the transmission of skill in the individual worker." 
Marx, who has attributed these views by a convenient fiction ${ }^{1}$ to Hodgskin, has drawn the parallel between natural and cultural history: accumulation through inheritance among plants and animals is the same as assimilation of skills and primitive or original accumulation among human societies.

Reproduction of the working class includes on the one hand the biological reproduction of workers, families and, where the part becomes the whole, societies. On the other it "includes the transmission and storage of skills from one generation to the next". ${ }^{2}$ It would be false to limit the process of transmission to the relation between generations, however, as though this relation, with the implied sexual reproduction, is all that there is, as though that transmission is biologically linked. On the contrary, it is a social-cultural matter which is stored and transmitted by the learning process. The storage and transmission, again, has a biological parallel, and it would be false to separate the cultural from the natural continuum, as though humanity had no relation to nature. The statements pertaining to culture by many anthropologists, whereby culture, symbolization or reasoning are attributed to humanity in absolute exclusivity, are a defective dialectic. The storage and transmission of learned skills, being acquired during the lifetime of the individual, are not the same as the processes of storage and transmission of genetic traits. The storage process relative to acquired traits is simply analogical to the storage process relative to genetic traits; the transmission process of the acquired traits is mediated by the culture, whereas the storage of the acquired traits is mediately a natural, but immediately a cultural process. The problem of transmission of acquired traits, as it was viewed by Marx in the light of Darwin's theories, is other than the view of the matter in biological theory today; but in neither case is a direct equation between storage of skills and hereditary storage possible.

The human being not only modifies nature outside his organism, as well as the nature of his own organs, or his internal nature; the human being in society modifies the instruments through which he works upon the natural surroundings and modifies his own nature, i.e. skills of hand, eye, etc., relative to his instrumentarium. Further, we have been able to perceive since Marx's day that the field of human culture

${ }^{1}$ Marx is putting his own formulations into Hodgskin's mouth: Hodgskin is given a fully developed Darwinian interpretation of accumulation and hereditary descent 34 years before the appearance of Darwin's work, and is also the master of the dialectic of subject and object (see Marx, ibid., p. 290, in reference to the capitalist as personified capital).

2 Marx, Kapital, Vol. 1, p. 599. 
is itself not a direct continuum with the natural field, but is itself modified. Thus, if we observe the pasture in which domesticated animals graze, we find that it is discontinuous with the wild, untended pasture, even though the same grass grows in both. The pastoral animals differ, their movements, communities, numbers, density and feeding habits differ, the use that they make of the grass differs, the size of the grazing plot, the laws regulating its use are all discontinuous with the natural fields, ground and feed, while at the same time continuous; that continuum is at once direct and indirect. Before proceeding into the contemporary discussion, however, we should examine the further development of Marx's own ideas.

Marx likened the division of labor in the factory, in which, be it noted, there is no commodity exchange, to a production mechanism whose organs are human beings. ${ }^{1}$ Although the likeness of the factory to an organism is but an image, yet it is important to note for the development of the caste which petrifies a human skill and a guild which ossifies it in a particular trade and its product. "Castes and guilds", wrote Marx, "arise out of the same law of nature which regulates the division of plants and animals into species and subspecies, save that at a certain grade of development the inheritance of castes or the exclusiveness of guilds is decreed as a social law." Castes and guilds are regulated by social laws under any and all circumstances, at whatever grade of social development they arise. It is the explicitness with which their social practices of inheritance or exclusivity is decreed that varies historically. The parallel between the natural and cultural processes is further developed by Marx relative to the special skill of the Indian weaver, which is "accumulated from generation to generation and bequeathed from father to son"; and this, says Marx, provides the Hindu, like the spider, with his virtuosity. In a note to the same passage Marx comments that the Indian loom is upright and its warp is vertically stretched ; $;^{2}$ but this skill at the loom provides the Hindu weaver with another virtuosity than the spider's.

The reader will readily grasp the similarity and difference between the culturally determined weaver's skills and the natural skill of the spider. Here we are faced with a different dialectical moment than that of nature-culture, it is that of process and its congelation in the end result, or the relation of living and dead labor time, and this dialectic was developed elsewhere by Marx. Marx himself restored the dialectic of nature and culture, with reference to the problem of castes, in a later note that he composed on the matter, and, as the final moment of the

1 Marx, Kapital, Vol. 1, p. 358; Le Capital, op. cit., p. 147.

Kapital, Vol. 1, p. 360. 
dialectic of nature-culture, he pointed to the division of society into classes by means of caste formations. On the one side, castes are the petrification of the gentile principle, that is, the principle of blood relation, on which differences of rank are imposed. But they do not come of themselves, and Marx asks if it is not by the external factor of conquest that the castes are formed among the ancient gentes. Caste is the opposite of the feeling of equality, the gens cannot end up in a finished aristocracy. ${ }^{1}$ The genetic course of the caste is opposed to its functioning under historic conditions. The Republic of Plato depicts a system of division of labor which is but the Athenian idealization of the Egyptian caste organization. ${ }^{2}$ In order to make the passage from the genesis of caste by blood relation and conquest to the functioning of castes as an ossified division of social labor, several further factors have to be introduced: bondage to the soil and in localities; the organization of communities that are not primarily agricultural but are bound by relations of social labor and kinship here and there through a nation of considerable size; the bondage, again, is not to a person as we find the case to be in slavery, serfdom, clientage-patronage, but a bondage of tradition, custom, habit or feeling. ${ }^{3}$ These terms, which characterize the relation of the Indian peasant to the soil, are applicable to the Indian caste system generally. That is the first thesis. The second is that in a preponderantly agricultural society the relation throughout the society, whether rural or urban, courtly or common, will be determined by the agricultural relation. Thus, the form of bondage to the soil being non-personal in traditional India, the relation of bondage in the Indian caste system was the same.

The law of nature that governs the formation of castes and guilds is the same law that governs the speciation of plants and animals. That is not the same law that governs the exercise of caste functions. The parallel between nature and culture is in turn governed by individual variation. The restriction on caste development once formed and finished is the contradiction of individual variation; it is the social law that is in this case the contradiction of the natural law. The dialectical moment nature-culture is crossed by the moment of genesisfunction or genesis-structure; a further contradiction is generated, but this does not decree its own elimination. Why not? Because the cultural or social law restricting human variation and innovation overwhelms the natural law; there is no contest, natural development gives way to the social decrees for considerable periods of time; the entire society must pass away before the particular contradiction can

1 Ethnological Notebooks, op. cit., p. 183; Introduction, pp. 14-16.

2 Marx, Kapital, Vol. 1, p. 388.

Ethnological Notebooks, p. 255. 
be abolished: videlicet, the thousands of years of ancient Egyptian or traditional Indian society. Marx propounded economics as a natural science, because of his grasp of the evolution of economic formations of society as a process of natural history. ${ }^{1} \mathrm{He}$ grasped both nature and society as history, hence as change; by the study of society, whose nature is change, he came to the change of nature. The economists his contemporaries, on the contrary, appealed to laws of nature as eternal in order to affirm the same of the laws of economics which they engendered. The course goes the other way in Marx's thought; therefore economic categories of capitalist and landowner as personifications are raised up by Marx as subjectivities. The parallel with nature need not be sought because natural history is not the source of the categories; it is social. They seem to be objective and natural because the subjectivity in them assumes a petrified form. It is transformed into a thing; it is reified, the end result of a process of taking a whole man, subject and object, draining him of his subjective life, and substituting an objective relation of capital for the vacancy created. At the same time the converse movement takes place, the attribution to the objective moments of capital and of private property in land the subjective motivations of desire and will. The combined dialectical processes are in the one case the reification of the human being, in the other the personification of capital. The two processes are related, as we have seen, but they are not the same.

\section{IX \\ OBJECT AND THING. OBJECTIFICATION AND REIFICATION}

When Feuerbach wrote that man is nothing without an object, he had in mind the process whereby we create our own human condition. $\mathrm{He}$ held that the world of objects that we create is the means of creation of our subjective condition and thereby of our own objective nature: "Every planet has in its sun the mirror of its own nature." Further, he said, we can only, know ourselves by contemplating the world as object and ourselves as object. ${ }^{2}$ Out of this philosophy and in opposition to it Marx set forth the positions of alienation and objectification that at first caused him to be taken for a humanist. The irrelevance of Feuerbach to the human sciences today arises out of its generality; because

1 Kapital, Vol. 1, p. 16. It is not that human science is like natural science because the latter is unalterable. On the contrary, natural is like human science because each has its history, just as natuse and humanity are one in that each has its history: to this extent they are unlike the law of the Mecles and Persians which altereth not.

${ }^{2}$ Feuerbach, Das Wesen des Christentums. 
it speaks to all humanity it speaks to no one in particular. For a related reason, alienation cannot be the starting point in the analysis of the troubles of capitalism, for it is too general a phenomenon, and while it has a bearing on our own times, yet the particularity and the generality within it have not been parsed out. It is of fundamental importance in considering the human condition in the abstract; it is a fundamental issue in the critique of capitalism, but its nature is changed when proceeding from the abstract to the concrete case.

The question of objectification and reification are of the same sort as that of alienation, and if we treat of them it is because they have been handled and mishandled by a number of writers; their treatment, moreover, has a bearing both on the principles and the contradictions of a Marxist anthropology. Lukács took up the matter of reification in an attempt to explain the revolutionary consciousness of the proletariat; the end result of his treatment was an explanation of the decline of the revolutionary consciousness of the proletariat by the phenomenon of reification. The historical event of the October Revolution in Russia, the high point of class-consciousness associated with it in all parts of the world, the subsequent retreat of the revolutionary wave, are only partly accounted for by Lukács; his work is not an analysis so much as a segment of the protocol, bearing witness to the course of the events. ${ }^{1}$ As a theory of revolution it lacks precision; as a theory of a social phenomenon, whether in a revolutionary period or outside of it, it is wanting in Marxian categories. Elsewhere we have shown that reification is divided as social classes are divided in capitalism, ${ }^{2}$ but it is still not the underlying problem of society. It is the response in the head to the underlying problem. The problem of reification has been of late obscured because it has been applied indifferently as objectification. ${ }^{3}$

The objectification of the world is a twofold process, on the one side creation of the object, and, on the other, standing to it as object. Scientific objectivity is an aspect of the second sense; objectification of self, consciousness of self are derivative of that second sense. The first sense is a sensory act and the physical action of hands, or any other body organ. The action of objectification is necessary for life sustenance in an abstract sense; every human being creates the object that he acts upon. There is nothing praiseworthy or pejorative about

1 Georg Lukács, "Die Verdinglichung und das Bewusstsein des Proletariats", in Geschichte und Klassenbewusstsein (1923).

\& Lawrence Krader, "Verdinglichung und Abstraktion in der Gesellschaftstheorie", in Ethnologie und Anthropologie bei Marx, op. cit., pp. 178ff.

${ }^{3}$ Hannah Arendt, op. cit., pp. 122, 148; Herbert Marcuse, "Re-examination of the Concept of Revolution", in: Diogenes, No 64 (1968), p. 25. 
objectification, the act is free of subjective valuation, and exists only in the objective world. The objective judgment corresponds to the act and is likewise free of subjective valuation. ${ }^{1}$ We can go further into the question of value-freedom if we introduce the relation of subjective to objective value and the value-freedom on either side, but we question whether the game is worth the candle. We call attention to the naming: what is usually referred to as "value-free" is "free of subjective value"; objective value-freedom is a circularity.

Reification on the contrary is inseparably tied to a valuation, both subjective and objective. The creation of a thing implies the separation of the human from the thing. The act of objectification implies no such separation: we become human subjects by virtue of having made the objective world and ourselves into an object. Labor as such is a relation to the world; the making actual of labor is its objectification. ${ }^{2}$ It is by means of a factor external to the labor relation, namely the appropriation of the object by another, that the worker becomes dehumanized, or entwirklicht (= deactualized). Objectification per se is neither a plus nor a minus, neither inhuman nor dehumanizing, it is neutral until it enters the market place. Reification, Verdinglichung or Versachlichung, on the contrary, is intrinsically inhuman because dehumanizing. The argument of the passage on commodity fetishism in Capital rests on the identification by Marx of the material relation of persons and the social relation of things. ${ }^{3}$ The material relation of persons is a reification; the social relation of things is a hypostatization. The former is the materialization of the social, which is both sensory and suprasensory or material-supramaterial; the latter is the etherealization of the material. ${ }^{4}$ In either case it is a defective because onesided relation.

1 Max Weber, Gesammelte Aufsätze zur Wissenschaftslehre, 3rd ed. (1968), pp. 146ff., 489ff. Weber ought to have separated these thoughts, but did not do so.

${ }^{2}$ Marx, Ókonomisch-Philosophische Manuskripte, p. 83.

${ }^{3}$ Marx, Kapital, Vol. 1, ch. 1, section 4; Vol. 3, pp. 835f., $838 \mathrm{f}$.

${ }^{4}$ It is easier to find the earthly core of the abstract relations, to show the material basis of the relations between persons; this is the task of criticism, of analysis, science and materialism. It is more difficult to evolve out of these earthly relations the mystifications, abstractions. Why do we perform the more difficult task instead of the easier one? The etherealization or hypostatization is the abstraction of the human being, his transformation into a juridical person, etc. The social usefulness of this has already been seen. Disclosure of the material relations between persons is a process that leads in two directions. First, it is the critical analysis itself; the human being has been made into an abstract, juridical person, the representation of a relation that has its material base. Second, the human being has been made into a material of the process of production, the source of labor power, whose labor time as living labor is converted into dead 
The defect of the dialectic in this case is at once the source of the reification and its result. That a social relation, which in itself is immaterial, while in its expression is at once material and immaterial, is realized in reified form is the result of its promulgation not through human beings but through persons, juridical fictions. Therefore the relation between them cannot be anything but onesided, the material relation between persons, or the reification of the social relation. The hypostatization of the relation between things, commodities, is their fantastic existence as though they were social. They are in fact the material side of the social relation which is taken to be the entirety, material and supramaterial, sensory and suprasensory, in commodity fetishism, just as the material relation between persons is the unilateral relation that substitutes under capitalist conditions of exchange for the relations between whole human beings. The juridical person is the fantastic representation of the material side of the human being, the onesided form, which, as we have seen, has been developed in society in order to realize the commodity-exchange relation, the sale and purchase of labor time, living and dead, labor capacity. This is then substituted for the whole human being. The human being under all circumstances objectifies himself in the labor relation, be the labor capitalist or communal, private labor or public, be it social labor or labor in the family. The objectification is turned into a dehumanized process, a dysvalue under the capitalist process of extraction of surplus value. The worker is reified in the process of production, the capitalist in the process of circulation of capital; the intellectual is reified in the process of abstraction. His social act is a hypostasis, whereby the subject is alienated from the object; thereby the consciousness of the intellectual is reified. Reification stands to objectification as its negation, whereby the subject is reified at the same time; but objectification is not the negation of the reification. In political society it becomes a form of reification.

We have seen that the objective side of the human being is necessarily bound to the subjective: the human being is subject-object; without the subject, no object, without the object, no subject, without the combination of both, no human being. There are two objects, however, the object in nature and the human object. The natural object is not paired with the subject, it is neither subject nor object, but neutral. Its neutrality, as it is natural, is wholly objective. The human being is both subject and object, hence he bears his partisanship

labor. This is the reification of the human being; it is the second dialectical moment of another process as well: the etherealization, hypostatization, abstraction of the human individual is the preparatory stage for the reification. See Marx, Kapital, Vol. 1, p. 393, note. 
within himself. The human being can be spokesman and representative of his private interest, of the interest of all humanity, and of all nature; the human being is the bearer of all these interests, which are given subjective and objective expression within himself. He is not neutral, but bears both the subjective and the objective relations to and within society, to and within nature. These relations in no way negate each other, nor cancel each other out ; they are opposite and complementary, coincidentia oppositorum. Further, the human being objectifies himself and makes himself into subject. These are the primary subject-object relations, and the primary subjectification and objectification.

Making the human being into a natural object, the secondary objectification, is false, for he is already object. The secondary objectification is actually a tertiary one, which comes about in this way. The human being, having discovered the object in nature and the subject-object within himself, thereupon proceeds to a twofold projection. He projects the natural object onto the human domain, and the human object-and-subject onto the natural. The natural object and the human object are thereby taken for one another, confused one for the other, falsified and distorted. The natural object is treated as though it were the human object; and a natural subject, complete with will and consciousness, is invented. On the one side, the natural object is given the character of human objectivity; on the other, the neutrality of the natural object is projected onto the human object. The human subject is projected onto the world of nature; the subject reads his pathos in nature (waves at sea threaten, the sunny day smiles). The list of pathetic fallacies has long been made. The human subject, alienated from the human object, is projected, the one onto the other.

Social-scientific research has perpetrated the objective fallacy. Here the assumption is made that the human object and the natural object are one. The neutrality of the natural object, which makes neither moral judgments nor value judgments, is transposed to the human object. The human object is thereby artificially alienated from its natural pair. The result is the reified human object of social-science research, whereby the human being is turned not into natural object but into thing. The positive science of humanity, value-freedom and neutrality with respect to human beings are fallacies, whose grounds are not far to seek. The natural sciences have met with great success, constructing electric, electronic, atomic, chemical energy devices, from which the social sciences wish to profit. The temptation is too great to resist. But more than this, there are the undoubted successes of opinion polls and marketing analysis, together with the predictions that have followed from the pollings and analyses in political behavior and marketing behavior. These successes have been made possible because 
the artificial alienation of the human subject-object in the social sciences, economics, social psychology, political sociology, accomplishes in these fields what has already been accomplished in society in fact. The human being in political society has been actually reified in the process of politicking, trafficking, marketing, buying and selling himself, his labor capacity, his product. The alienation of self from self, of object from subject, is a daily event. The choice between parties, as between commodities, wares, is appearance of choice, not the reality, having as its result the false objectification of the human subject. Therefore, the social-science method is justified, but only insofar as it is not the human object that is taken up, but a false natural object.

Theodor Adorno had taken up reification not as a social, still less as an economic, but as a metaphysical category. ${ }^{1}$ Lukács had seen in reification a condition of the consciousness formed by a condition of society. It is possible to go forward with the analysis of Lukács into the separate forms of reification in the different social classes; it is not possible to do so with Adorno's. In the latter case, the mode of treatment of reification metaphysically, instead of as it is, the deformation of social relations, and the consciousness thereof, by the spirit of spiritless conditions, by routinized labor, by formal freedom and pseudo-equality, merely evidences the spread of the phenomenon to social areas beyond its immediate field of activity. It is a part of the problem, not its solution. ${ }^{2}$

1 Theodor Adorno, Negative Dialektik (Frankfurt, 1966). He writes, p. 365: "Dass der Kategorie der Verdinglichung, die inspiriert war vom Wunschbild ungebrochener subjektiver Unmittelbarkeit, nicht länger jener Schlüsselcharakter gebührt, den apologetisches Denken, froh materialistisches zu absorbieren, übereifrig ihr zuerkennt, wirkt zurück auf alles, was unter dem Begriff metaphysischer Erfahrung geht."

2 The putative etiology of reification, which Adorno identified as its inspiration or the "wish-thought of unbroken subjective immediacy" (see the preceding note), is a symptom of the ailment first identified by Marx. Having taken the phenomenon out of society and deposited it within the domain of metaphysics, it is fitting to derive it as Adorno has done. What this derivation has to do with the phenomenon is clear: Adorno correctly distinguished between reification and objectification, but he made reification into a subjective metaphysical category instead of what it is, the elimination of the subject and of subjectivity, the substitution of relations that are external to the human being for the gap created, and the creation thereby of a new Adam and Eve who are only partly conscious of their loss. To the extent that we are unconscious of what we have undergone we are a simulacrum, the combination of pseudo-human, pseudosubjective conditions. The processes of the elimination, substitution and new construction differ with each social class. The intellectuals, by their power of abstraction and hypostasis, which results from their abstract relations in society, can, like the bees, gather their pseudo-nectar from the flowers of evil of the other social classes. If Adorno meant Lukács by the reference to apologetic thinking, 
The contradictions within anthropology are twofold: those that can be resolved, and those that, within the given state of society, cannot. The latter are imposed by the genesis and historical course of anthropology. Academic in its origins, anthropology early had positive science, natural science as its principle. Its method and end to this extent had been the establishment of universals, iron laws, invariant abstractions of human nature in the name of objective science. But since such undertakings are derived from a fallacious image of natural science, they are in contradiction with the matter of anthropology, human life in historically concrete societies. This contradiction is irresoluble, falling outside the dialectic, hence outside scientific method, and is subject to the criticism of the latter. On the other hand, there are contradictions that may be resolved in anthropology. The criticism of the discipline is sometimes made that it is the offspring of imperialism, as though there had been neither anthropology before the modern era nor anthropology developed by peoples subjugated through

he should have said so; otherwise this remains a hidden attack; it is an argumentum ad hominem even if the target is not named. Reification is not a concept of metaphysical experience, but the effect on the human body, brain and consciousness of relations in society. The relations in primitive society, as recounted in the mythology, point to a primary reification; those of capitalist society point to class-divided modes of reitication. On the former, see my article "Primary Reification in Primitive Society", in: Diogenes, No 56 (1966).

Reification has been taken up as a problem not of metaphysics but of history by H.-J. Krahl, Detlev Claussen, Oskar Negt et al., Geschichte und Klassenbewusstsein Heute (Amsterdam, 1971). Krahl speaks of the opposition reification-emancipation (p. 39); reification and abstract labor (p. 28); and reification in connection with legitimation theory (p. 40); Negt, Claussen and Krahl of reification and party organization (pp. 26, 41f.). The discussion moves in a direction 180 degrees counter to that of Adorno. The organization of political parties is a historical phenomenon of bourgeois-capitalist society; it is historically conditioned. The reification of the party organization does not come from metaphysics, nor from the historical conditions directly; several steps were omitted from the discussion. Reification in politics comes from the reified relations in economy and society, which set forth the political relations of party organization in reified form. Lukács's theory of reification was an explanation of the given state of the class conflict (1920-23) in Central Europe; it was conditioned by the reification of the historical relations of economy and society at that time; it is a reified theory insofar as it posited, but did not criticize, its own historical foundation. A complete theory, or the step toward one, should carry these criticisms forward. Krahl (p. 19) mentions the reification of social relations and the subjectification of objective labor conditions. If by this juxtaposition a systematic connection is meant, then it should be amended : reification is the elimination of the human subject and the substitution of thing for object in the economic relations and the historical process of society. Thing and object are not the same, reification and objectification are not the same; thing and subject are not the same, reification and subjectification are not the same. 
imperialism. These anthropologies exist, however, and stand both historically and synchronically in contradiction to each other; unlike the contradictions of the pseudo-scientific method, they can be overcome by their conversion from theory into the practical criticism, in the first place of the anthropologizing society, in the second of the anthropologized. 